\title{
RELATIONSHIP AMONG DENSITY MEASUREMENTS AND COMPOSITION OF DIFFERENT MEATS
}

\section{RELACIÓN ENTRE LA MEDIDA DE DENSIDAD Y LA COMPOSICIÓN DE DIFERENTES CARNES}

\author{
Olga Lucía Torres Vargas ${ }^{1}$, José Manuel Barat Baviera², Marta Aliño² \\ ${ }^{1}$ Universidad del Quindío. Programa de Ingeniería de Alimentos. ${ }^{2}$ Universidad Politécnica de Valencia, Camino de Vera s/n, 46022, \\ Valencia, España Grupo de Investigación e Innovación Alimentaria. Departamento de Tecnología de Alimentos.
}

Recibido: Agosto 3de 2010

Aceptado: Noviembre 30 de 2010

Correspondencia Programa de Ingeniería de Alimentos, Universidad del Quindío, Av. Bolivar calle 12 norte Armenia Quindio. Correo electrónico: oltorres@uniquindio.edu.co

\section{ABSTRACT}

Composition of fresh and frozen meat products, specially fat content, is one of the parameters that is usually taken into account for different purposes such as classification of fresh and frozen meat pieces for fresh consume as well as for processing, price fixation and adequacy for processing. That is the reason why some different non destructive methods are used to determine, at least approximately, the meat composition. Among them, we can go from visual methods to the more complex resonance imaging and computed tomography image analysis.

The aim of this study was to use density measurement as a non destructive, easy and cheap method to classify fresh and frozen meat with a wide range of fat content. The obtained results showed that there is a significant relationship between density and fat content of fresh and frozen meat.

Keywords: meat composition, density, freezing, fat content

\section{RESUMEN}

La composición de los productos cárnicos frescos y congelados especialmente el contenido en materia grasa, es uno de los parámetros que usualmente se toma en cuenta para diferentes fines como: la clasificación de piezas de carne fresca para su consumo en fresco o para su procesamiento, la fijación de precio y la adecuación para su transformación. Esta es la razón por la cual diferentes métodos no destructivos son utilizados para determinar, al menos aproximadamente, la composición de la carne, entre ellos podemos pasar de los métodos visuales a los más complejos; las imágenes por resonancia y el análisis de imagen por tomografía computarizadas.

El objetivo de este estudio fue el uso de la medida de densidad como una herramienta para clasificar la carne fresca y congelada de acuerdo a su contenido de materia grasa. Los resultados obtenidos muestran una relación significativa entre la densidad el contenido de grasa en carne fresca y congelada.

Palabras claves: composición de la carne, densidad, congelación, contenido en grasa.

\section{INTRODUCTION}

The measurement of the density of pieces of meat, Fruits, vegetables and cheese by weighting is possible by means of Archimedes Principle. This one state that a body immersed in a fluid is buoyed up by a force equal to the weight of the displaced fluid. The density of a substance is equal to the mass of the substance divided by the volume that it occupies (1).

Density is an intensive magnitude, in other words, the density of a body only depends on its composition. It is related with the amount of material accumulated (a compacted body is generally more dense than a scattered one), but also with its weight (2). That is the reason why it could be possible to determine the salt, protein, fat and water content of a piece of meat by a simple measurement of its density.

The meat packing industry has an urgent need for rapid, relatively accurate, and simple methods for moisture and fat determination. Their availability underlies 
compliance with statutory requirements of regulatory agencies, quality control in manufacturing meat products, and good business management. In general, moisture and fat methods are chosen for either rapidity or accuracy, whereas obtaining both is the ultimate goal. Among these methods, specific gravity measurement has been proposed to determine fat content in meat. Mahmood (3) proposed determining fat content by measuring the specific gravity of solvent extracts of meat products.

Determination of fat content in meat by measurement of the specific gravity of the meat itself was developed by Whitehead (4) and the study was completed by Malanosky (5) on meat samples of varied origins. The instrument contained a balance, integrated logic circuits, and a volume measuring device so that the amount of fat could be read directly. Therefore, this apparatus measured weight, compacted volume, and temperature of the samples. This appears to be the most rapid method for assaying fat content but from the published results, it is less accurate than other methods and additionally has the disadvantage of requiring meat samples with adequate size and shape to fit properly inside the compacting holder.

The measurement of density, as a prediction system of the composition of fresh and frozen meat, offers to the meat sector a technique for the classification of raw materials, ensuring the quality of meat to be marketed as a fresh produce or as raw material to elaborate meat products, improving the control of quality by means of monitoring the different stages of processing and storing of raw materials and products that are obtained.

The food industry makes use of non-invasive testing techniques which are fast, simple and have a low cost, such as the density. These techniques will be reflected in the ease to make analysis in situ with real- time results, the application of control of quality to the process, the easy use by non- qualified personnel decreasing the number of samples analyzed in the laboratory, and so the use of chemical reagents and production of liquid and solid wastes to the environment. All these factors will be profitable and optimize the production conditions in the meat industry.

The aim of this work was to evaluate the adequacy of measuring meat density by applying the Archimedes principle for prediction of meat composition working with different meat products.

\section{MATERIAL AND METHODS}

\section{Raw material}

The raw material used in this study was fresh and frozen meat of different parts of beef, pork, chicken and turkey with a wide range of fat content. The measurements were carried out on samples of $20 \mathrm{~g}$ of weight cut into slices of $4 \times 3 \times 1 \mathrm{~cm}$. Fresh meat weight and density was measured by using the Archimedes principle (samples were submerged in water)(7). Afterwards, samples were frozen, stored for 1 week at -20 으 and their weight and density was measured again. Finally, samples were thawed in a cold chamber at 4 으 for 4 days. Each sample was thoroughly homogenised before determining the moisture, sodium chloride, fat and protein content.

\section{Analytical determinations}

Sodium chloride was determined after sample homogenization in a known amount of distilled water at $9000 \mathrm{rpm}$ in an ULTRATURRAX T25 for 5 minutes and centrifuged to remove any fine debris present in the sample. Afterwards, the solution was filtered and a sample of exactly 500 I aliquot was taken and titrated in Chloride Analyzer equipment (CIBA Corning Mod. 926). Moisture content was determined by oven drying to constant weight at $100^{\circ} \mathrm{C}$. Fat content was determined by the Soxhlet method Nitrogen (N) content was measured by the Khjeldal method (AOAC 1990), and protein content was calculated as N·6.25 (7).

\section{Statistical analysis}

The data of each experiment were analysed by multiple regression analysis and the forward selection method, using the STATHGRAPHICS ${ }^{\circledR}$ Plus 5.1 version software (Numagistics Ltd).

The influence of water, fat, protein and salt content as well as the influence of the type of meat on density of fresh and frozen meat was evaluated.

The model included density of fresh meat and relative density change of density after freezing as dependent variables.

\section{RESULTS AND DISCUSSION}

Relationship between fresh meat density of different origins and its composition

The measure of density of different types (beef, pork, chicken and turkey) of fresh and frozen meat and its 
following analytical determinations looked forward to elaborate a non destructive method to predict fresh and frozen meat composition.

The statistical analysis of fresh meat density as a function of its composition $x w, x g, x p$ and $x \mathrm{NaCl}$ and meat type (beef, pork, chicken and turkey) was done by means of Statgraphics ${ }^{\circledR}$ software, ver. 5.1. The obtained prediction equation (Eq. (1)) relates the meat density with the lineal and quadratic term of the fat content, and distinguishes the chicken meat from turkey, pork and beef meat.

$\rho_{o}\left(\mathrm{~g} / \mathrm{cm}^{3}\right)=1.071-0.2819 \cdot \mathrm{x}^{\mathrm{g}}-0.63 \cdot($ chicken $) \cdot \mathrm{x}^{\mathrm{g}}+0.1869 \cdot\left(\mathrm{x}^{\mathrm{g}}\right)^{2}$

$$
r^{2}=0.94(1)
$$

Since the P-value in the ANOVA table is less than 0.01, there is a statistically significant relationship between the variables density o $(\mathrm{g} / \mathrm{cm} 3)$, fat content $(\mathrm{xg})$ and meat type (chicken) at the $99 \%$ confidence level.

To analyze properly the effect of variable fat in different kinds of meat, it was determined the value resulting from the sum of the terms that comprise the mass fraction of fat $(-0.281 \cdot x g+0.1869 \cdot(x g) 2)$ and was represented this value in relation to the mass fraction of fat (xg) as it is shown in figure 1 . As it can be observed meat density decreases with fat content. The line shows two different behaviours, a higher decrease of meat density for samples with low fat weight fraction and a progressive reduction of the decrease as fat content increases.

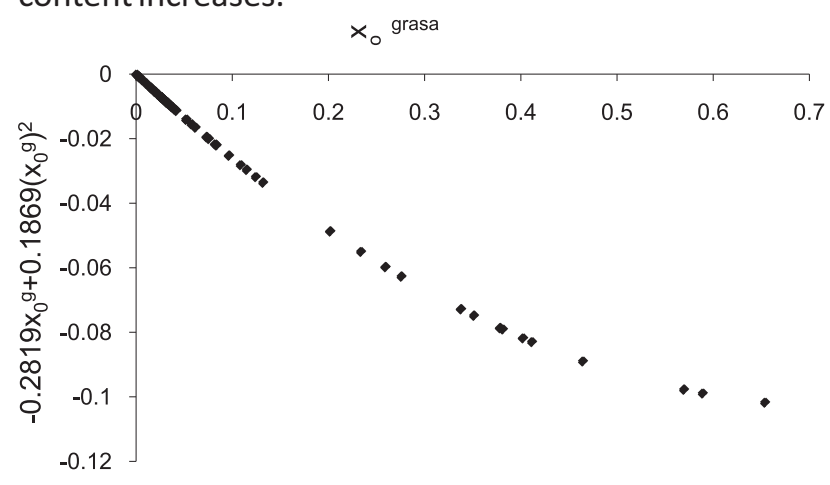

Figure. 1. Component effect of fat content on fresh meat density asurements (Equation 1).

Figure 2 shows the relationship between the experimental and the predicted values obtained by means of equation 1 . Since points in the graphic are distributed around the main diagonal we can consider that the fitted model is suitable to predict fresh meat density values.

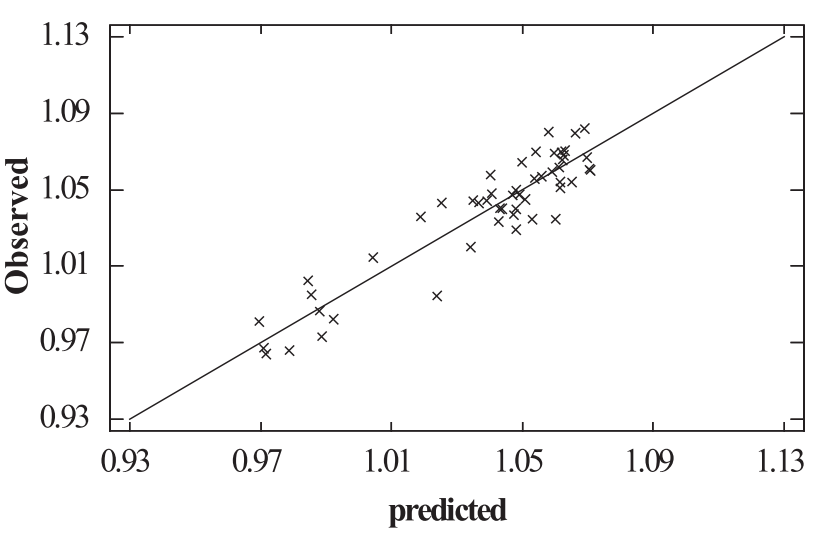

Figure.2. Experimental versus predicted values of fresh meat density measurements (Equation 1).

The different behaviour of chicken meat from the other types of meat could be explained by taking into account the main compositional parameters of the fatty acids of each type of meat (except turkey as its fat content was very low and did not result significant). Data corresponding to the percentages of type of lipids (saturated, monounsaturated and polyunsaturated) in chicken, pork and beef are shown in table 1. As it can be seen, chicken meat has a significantly higher amount of polyunsaturated fatty acids than pork and beef. This fact, in combination with the lower amount of total saturated fatty acids, implies a lower density of the fatty phase in chicken meat, as indicated by the component effect of the interaction of the total fat composition with the dummy variable corresponding to chicken (negative term).

Table 1. Percentages of type of lipids (saturated, monounsaturated and polyunsaturated) in chicken, pork and beef (8).

\begin{tabular}{lccc}
\hline \multicolumn{1}{c}{ Fatty acids (\%) } & Chicken & Pork & Beef \\
\hline Total saturated & 31 & 39 & 46 \\
Monounsaturated & 47 & 49 & 50 \\
$\begin{array}{l}\text { Poyunsaturated } \\
\text { Sumo of Mono and }\end{array}$ & 22 & 12 & 4 \\
Polyunsaturated & 69 & 61 & 54 \\
\hline
\end{tabular}

Changes on density after freezing

Meat freezing involves the water phase transition from liquid to solid, this leads to an increase of the volume of around $6 \%$ at the end of the process. Therefore, density of frozen meat decreases (9). As water is mainly the only component of meat that changes during freezing, we can expect that the measurement of the frozen meat density could be related with its composition. 
The results of fitting a multiple linear regression model to describe the relationship between relative density change after freezing and the type of meat, the composition ( $x w, x g, x p$ and $x \mathrm{NaCl})$, and the fresh meat density are shown in equation 2 .

$$
\Delta \rho=\left(\rho_{\mathrm{t}}-\rho_{\mathrm{o}}\right) / \rho_{\mathrm{o}}=0.653-0.664 \cdot \rho_{\mathrm{o}}-0.052\left(\mathrm{x}^{\mathrm{g}}\right)^{2} \quad \mathrm{r}^{2}=0.90
$$

Since the P-value is less than 0.01 , there is a statistically significant relationship between the variables fat content (xg)2 and fresh meat density (o) at the $99 \%$ confidence level. Figure 3 shows the relationship between the experimental and the predicted values obtained by means of equation 2 .

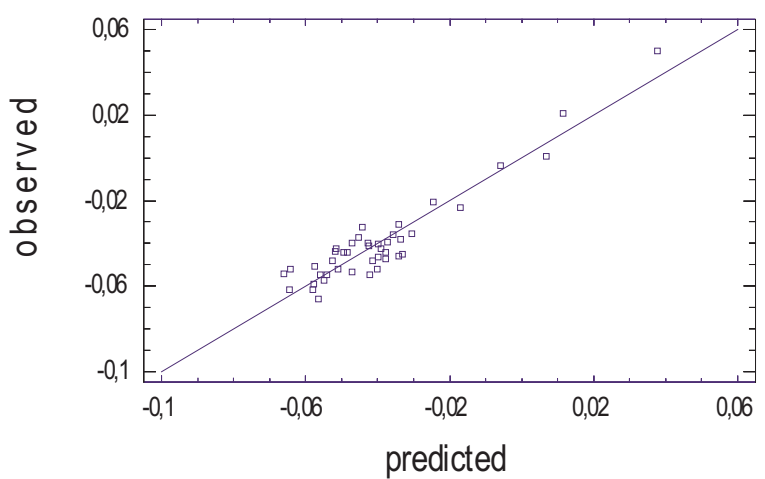

Figure 3. Observed versus predicted values of relative changes in meat density $(\Delta \rho)$ after freezing (Eq.2).

The fitted model showed how an increase of fresh meat density involves an increase of the relative density change after the freezing process. A higher fresh meat density would mean lower fat content and therefore higher water content. Since water is responsible for changes on meat density during and after the freezing process, it appears logical that higher water content would suppose an increase of relative density change. However, the other significant variable, fat content (xg)2, contradicts this relationship as it has a negative term that is why the component effect on fat content of both variables was studied. As it can be observed in Figure 4, relative density change after freezing decreases as fat content increases.

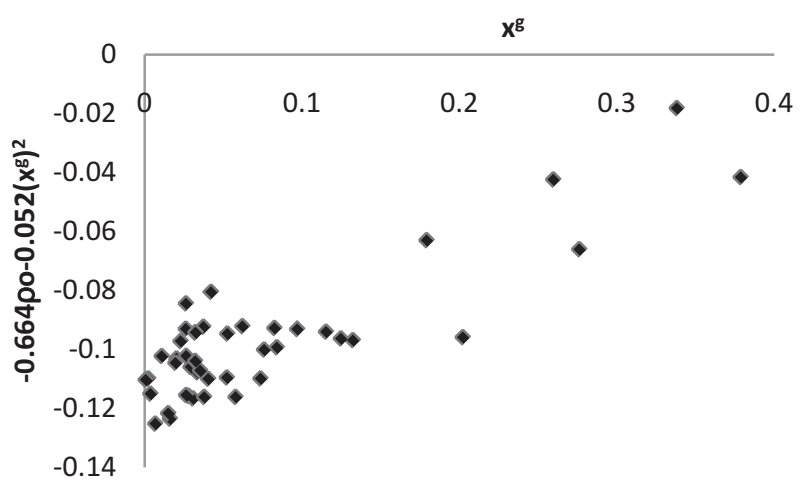

Figure 4. Component effect of both variables, fresh meat density (o) and fat content (xg) 2, on fat content (xg).

\section{CONCLUSIONS}

The results indicate that fresh meat density is related with its fat content, while significant differences were observed depending on the type of animal, due to differences in fatty acid composition. The measurement of density before and after freezing seems to be adequate for meat classification, with the additional advantage of being a cheap and easy method to do.

The prediction models, obtained through the measurements of density in fresh meat with different kinds, allow us to know the quantity of fat in situ, so it could be used as a measuring and control process at industrial level.

\section{ACKNOWLEDGEMENTS}

We wish to thank the Quindío University for the financial support given to this research. 


\section{BIBLIOGRAPHY}

1. Alvarado, J.D. y Aguilera, J.M (2001). Métodos para medir propiedades físicas en la industria de Alimentos. Zaragoza: Editorial Acribia.

2. Chiral, A., Martínez Navarrete, N. y Camacho, M.M. (2007). Propiedades Físicas de los Alimentos. Valencia: Editorial Universidad Politécnica de Valencia.

3. Mahmood-UI-Hassan. y D. Pearson. (2006). "The rapid determination of fat in meat products in routine industrial control". Journal of the Science of Food and Agriculture, (17), 421-424.

4. Whitehead, Robert. C. (1970). "Fat analysis of boned meat by the specific gravity method". Journal of Food Technology, (24), 469-496.

5. Malanosky, A. J. and Greenfield, E. L. (1970). "Rapid instrumental fat determination". Journal of the American Oil Chemists Society, (53), 1080-1085.

6. Torres, O.L. Puesta a punto de métodos no destructivos y de análisis rápidos utilizables en el proceso de elaboración de jamón cocido. (Tesis doctoral). Valencia: Universidad Politécnica de Valencia; 2008.

7. AOAC. (2000). "Official methods of analysis, 17th Edition, 3a Revisions". Association of official Analytical Chemists, Washington D.C., USA.

8. USDA. Database. http://www.nal.usda.gov/fnic/foodcomp/. Accessed July 30, 2010.

9. Choi, Y. and Okos, M. R. (1986). "Effects of temperature and composition on the thermal properties of foods". Food Engineering and Process Applications, (3), 5-15. 